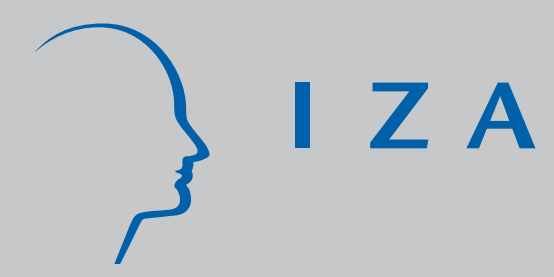

IZADP No. 1690

The Dynamics of the National Minimum Wage:

Transitions Between Different

Labour Market States

Melanie K. J ones

Richard J J ones

Philip D. Murphy

Peter J. Sloane

July 2005 


\title{
The Dynamics of the National Minimum Wage: Transitions Between Different Labour Market States
}

\author{
Melanie K. Jones \\ WELMERC, University of Wales Swansea \\ Richard J. Jones \\ WELMERC, University of Wales Swansea \\ Philip D. Murphy \\ WELMERC, University of Wales Swansea \\ Peter J. Sloane \\ WELMERC, University of Wales Swansea \\ and IZA Bonn
}
Discussion Paper No. 1690
July 2005

IZA

P.O. Box 7240

53072 Bonn

Germany

\author{
Phone: +49-228-3894-0 \\ Fax: +49-228-3894-180 \\ Email: iza@iza.org
}

\begin{abstract}
Any opinions expressed here are those of the author(s) and not those of the institute. Research disseminated by IZA may include views on policy, but the institute itself takes no institutional policy positions.

The Institute for the Study of Labor (IZA) in Bonn is a local and virtual international research center and a place of communication between science, politics and business. IZA is an independent nonprofit company supported by Deutsche Post World Net. The center is associated with the University of Bonn and offers a stimulating research environment through its research networks, research support, and visitors and doctoral programs. IZA engages in (i) original and internationally competitive research in all fields of labor economics, (ii) development of policy concepts, and (iii) dissemination of research results and concepts to the interested public.
\end{abstract}

IZA Discussion Papers often represent preliminary work and are circulated to encourage discussion. Citation of such a paper should account for its provisional character. A revised version may be available directly from the author. 


\section{ABSTRACT \\ The Dynamics of the National Minimum Wage: Transitions Between Different Labour Market States*}

An important policy issue is whether the National Minimum Wage (NMW) introduced in Britain in April 1999, is a stepping stone to higher wages or traps workers in a low-wage - nowage cycle. In this paper we utilise the longitudinal element of the Labour Force Survey over the period 1999 to 2003 to model transitions between different labour market states payment at or below the NMW, above the NMW, unemployment and inactivity, using a multinomial logit approach. It appears that for many workers payment at or below the NMW is of relatively short duration and a substantial number move into higher paid jobs.

JEL Classification: J0, J3, J6

Keywords: national minimum wage, transitions, steady state distributions

Corresponding author:

Peter J. Sloane

WELMERC

Economics Department

James Callaghan Building

University of Wales Swansea

Singleton Park

Swansea SA2 8PP

UK

Email: p.j.sloane@swansea.ac.uk

\footnotetext{
* Material from the Quarterly Labour Force Surveys is Crown Copyright, has been made available from the Office of National Statistics (ONS) through the UK Data Archive and has been used with permission. Neither the ONS nor the Data Archive bear any responsibility for the analysis or interpretation of the data reported here. We are grateful to the Low Pay Commission for the award of a research grant to support this project.
} 


\section{INTRODUCTION}

A National Minimum Wage (NMW) was introduced in the UK for the first time in April 1999. Acting on advice from the Low Pay Commission (LPC) the government initially set the adult rate at $£ 3.60$ per hour and the youth, or development, rate (for those aged 18 to 21 ) at $£ 3.00$ per hour. Since then the NMW has been regularly updated (see Table 1), normally in October of each year, and in October 2005 the adult rate and youth rates are set to increase to $£ 5.05$ and $£ 4.25$ per hour respectively. The NMW is now a well-established feature of the UK labour market and alongside Tax Credits and the New Deal it is seen as being an integral part of a government policy designed to tackle poverty and increase labour market participation (DTI, 2004).

Given the NMW is a major labour market intervention it is not surprising that it has increasingly attracted the attention of economists who are interested in examining the impacts it has had on labour market outcomes. Metcalf (2002, and 2004) provides an excellent and concise summary of some of the key findings, which have variously looked at issues related to coverage and the effect the NMW has had on employment, the wage distribution, and training. The general consensus from the UK literature is that the NMW has been a success. For example, NMW has improved the relative position of individuals in the bottom decile of the pay distribution without having created any major spillover effects further up the distribution (Dickens and Manning, 2004, and Stewart and Swaffield, 2002); there appear to be no adverse employment effects associated with the introduction of the NMW, even in those regions or sectors where it might have been expected to have the greatest impact (Dickens, 2001; Stewart, 2002, and Machin et al, 2003); and there is little evidence to suggest that the NMW has reduced the training of affected workers, in fact quite the reverse as there is evidence to 
suggest that training intensity has actually increased for many of these workers (Arulampalam et al, 2004).

Despite the work that has already been done on assessing the impacts of the NMW in the UK, there are still a number of areas that remain under explored. Thus, while there is now good information on which groups are most likely to be affected by the NMW, much less is known about the movements of individuals to and from jobs covered by the NMW. And yet, a fundamental question relating to the assessment of the impact of the National Minimum Wage (NMW) is not simply about how many employees are affected by it, either directly or indirectly, but also about what happens to these individuals over time. Specifically it is of interest to policy makers to know whether the NMW is a stepping-stone to higher wages or a trap from which it is difficult to escape, unless it is to from a low-wage to a no-wage cycle. Obviously if minimum wage jobs are mainly entry level jobs that only have a short-term effect on lifetime earnings this is a much less serious policy issue than if they are mainly dead-end jobs, providing workers with few opportunities to escape to better paid jobs ${ }^{1}$.

This paper considers some of these important issues by exploiting the longitudinal element of the Labour Force Survey to model transitions between various labour market states and the NMW. The analysis not only provides estimates of transition rates to and from jobs at or below the NMW but also steady state estimates of the distribution of 'workers' across different labour market states and an estimate of how long different types of workers might be expect to remain in jobs paid at or below the NMW.

\footnotetext{
${ }^{1}$ Recently Neumark and Nizalova (2004) have shown for the US that even by their late 20s individuals who have been on the minimum wage longer earn less and work less than other workers.
} 


\section{PREVIOUS WORK}

As far as we are aware direct evidence on the dynamics of minimum wages is limited to limited to work undertaken in the USA. One study (Smith and Vavrichek, 1992) reported that over $60 \%$ of workers in receipt of the minimum wage in 1984 were earning more than the minimum one year later. More recently Evan and McPherson (2003) compared minimum wage workers with a comparison group earning above the minimum, using panel data drawn from the Current Population Survey over the period 1979-1999. Their evidence suggests that minimum wage jobs tend to be entry-level jobs and that they are also of short duration for a large majority of workers. Factors most likely to assist wage growth (or movement above the minimum) are education and training and changes of industry and occupation.

As far as Britain is concerned work on the dynamics of low pay has some relevance (see, for example, Asplund, Sloane and Theodossiou, editors, 1988, Stewart and Swaffield, 1999 and Sloane and Theodossiou, 2000). One may summarise this literature as suggesting the longer workers remain in low paid jobs then the more difficult it becomes to escape from them (low pay persistence). This scarring effect of low pay can arise as a consequence of the characteristics of individuals themselves (heterogeneity) or the carry over of the experience of low pay from one period to the next (structural dependence). The evidence suggests that the latter is much more important than the former. As well as having a relatively high probability of remaining low paid, this group is also more likely to move out of employment (the low-pay, nopay cycle). There is no evidence that low paid jobs act as stepping-stones to higher paid jobs, which might offset the above disadvantage for some. Therefore, it does appear that experience of low pay causes some workers to be trapped there. Low pay 
appears also to be associated with long-run earnings inequality in the sense that as the earnings distribution widens the number of workers classified as low paid increases. To some extent, institutional arrangements, such as union membership and collective bargaining coverage, serve to moderate these effects by compressing the lower tail of the earnings distribution. Yet, we should be cautious in equating low pay with minimum pay. First, minimum wage workers are located at a lower moment in the earnings distribution than low-paid workers, who are conventionally defined as earning less than two-thirds of the male median wage and who are not subject to statutory wage provisions. Second, there are statistical problems in using standard data sets to identify those subject to the minimum wage that are much more severe than is the case with respect to low-paid workers.

A number of studies have focused on the incidence of minimum wages for particular groups in the labour market. The LPC itself estimated at the time of the introduction of the NMW in 1999 that it would impact on 3 per cent of male full-timers, 26 per cent of

male part-timers, 5 per cent of female full-timers and 22 per cent of female part-timers, implying that three-quarters of the recipients would be female. Despite this Dex, Sutherland and Joshi (2000) estimated the effect on the gender pay gap to be small. This result was confirmed by Robinson (2002) who suggests, on the basis of a simulation using the 1999 Labour Force Survey, it would require a NMW as high £5 per hour to reduce the pay gap by 3 percentage points.

\section{METHODOLOGY}

Following an approach used to model intra-firm mobility by Ransom and Oaxaca (2005) we assume movements to and from the NMW are determined by a Markov 
model, in which information on the distribution of the working age population across different labour market states at adjacent points in time are used in conjunction with an appropriately defined transition matrix - describing the probability of moving from one labour market state to another - to define a steady state labour market distribution. Formally, let $\mathrm{P}_{\mathrm{t}}$ be a (1xk) vector whose elements show the proportion of individuals occupying $k$ labour market states at time t. Similarly, let $\Omega$ be a (kxk) transition matrix whose $i j$ th element, $\omega_{\mathrm{ij}}$, indicates the probability of moving from labour market state $i$ in period t-1 to labour market state $j$ in period t. The $i$ th row of $\Omega$, therefore, shows the probabilities of moving from state $i$ in period t-1 to each of the $k$ possible labour market destinations at time t. The sum of these probabilities, therefore, must by definition sum to unity. It follows that:

$\mathrm{P}_{\mathrm{t}}=\mathrm{P}_{\mathrm{t}-1} \Omega$

which on recursively substituting for $\mathrm{P}_{\mathrm{t}-1}$ can be shown to equal:

$\mathrm{P}_{\mathrm{t}}=\mathrm{P}_{0} \Omega^{\mathrm{t}}$

where $\mathrm{P}_{0}$ is the initial distribution of the population across each labour market state.

As the Markov assumption implies the steady state labour market distribution, $\mathrm{P}^{*}$, is independent of the initial distribution, $\mathrm{P}_{0}$, we have:

$\lim _{\mathrm{t} \rightarrow \infty}\left(\mathrm{P}_{0} \Omega^{\mathrm{t}}\right)=\mathrm{P} *$

Assuming the steady state labour market distribution to be stationary Ransom and Oaxaca (2005) have shown, without any loss of generality, that the elements of $\mathrm{P}^{*}$ can be recovered from:

$\mathrm{P}_{1}^{*}=1-\sum_{\mathrm{i}=2}^{\mathrm{k}} \mathrm{P}_{\mathrm{i}}^{*}$ and $\mathrm{P}_{\mathrm{j}}^{*}=\sum_{\mathrm{i}=1}^{\mathrm{k}} \omega_{\mathrm{ij}} \mathrm{P}_{\mathrm{i}}^{*}$ for $\mathrm{j}=2,3, ., . \mathrm{k}$

Alternatively $\mathrm{P}^{*}$ can be written in matrix notation as: 
$\mathrm{P}^{*}=\mathrm{P}^{*} \widetilde{\Omega}+\mathrm{q}$

which on solving for the steady state vector $\mathrm{P}^{*}$ gives:

$\mathrm{P}^{*}=\mathrm{q}\left(\mathrm{I}_{\mathrm{k}}-\tilde{\Omega}\right)^{-1}$

where $\mathrm{P}^{*}=\left(\mathrm{P}_{1}^{*}, \mathrm{P}_{2}^{*}, ., \mathrm{P}_{\mathrm{k}}^{*}\right), \widetilde{\Omega}=\left(\begin{array}{ccccc}0 & \omega_{12} & \omega_{13} & \ldots & \omega_{1 \mathrm{k}} \\ -1 & \omega_{22} & \omega_{23} & \ldots & \omega_{2 \mathrm{k}} \\ \cdot & \cdot & \cdot & \cdots & \cdot \\ \cdot & \cdot & \cdot & \cdots & \cdot \\ \cdot & \cdot & \cdot & \cdots & \cdot \\ -1 & \omega_{\mathrm{k} 2} & \omega_{\mathrm{k} 3} & \ldots & \omega_{\mathrm{kk}}\end{array}\right), \mathrm{q}=(1,0,0, \ldots, 0)$ and $\mathrm{I}_{\mathrm{k}}$ is a (kxk) identity matrix.

In the analysis reported below the elements of the transition matrix $\Omega$ required to solve expression (6) are estimated in two ways. First, at the aggregate level, and where there are a large number of observations (i.e., for all workers and for males and females separately), the required elements of $\Omega$ can be estimated from observed transitions using the following estimator:

$\hat{\omega}_{\mathrm{ij}}=\frac{\sum_{\mathrm{t}=2}^{\mathrm{T}} \mathrm{E}_{\mathrm{ijt}}}{\sum_{\mathrm{t}=2}^{\mathrm{T}} \mathrm{N}_{\mathrm{i}, \mathrm{t}-1}}$

where $\mathrm{E}_{\mathrm{ijt}}$ is the number of individuals in labour market state $j$ in year t who occupied labour market state $i$ in year $\mathrm{t}-1$, and $\mathrm{N}_{\mathrm{i}, \mathrm{t}-1}$ is the number of individuals in labour market state $i$ in year $\mathrm{t}-1$.

Second, the required elements of $\Omega$ are also estimated from a multinomial logit model, which considers the probability of an individual moving between different labour market states between periods $t-1$ and $t$. Specifically, if $Y_{p}$ is a polychotomous variable indicating the destination of the $p$ th individual, starting in the ith labour market state at 
time $\mathrm{t}-1$ and moving to the $j$ th labour market state at time t, then using the multinomial logit model the probability of a ijth transition for the $p$ th individual is given by:

$$
\operatorname{Prob}\left(Y_{p}=i j\right)=\frac{\exp ^{X_{p} \beta_{i j}}}{\sum_{j=1}^{k} \exp ^{X_{p} \beta_{i j}}} \quad\left\{\begin{array}{l}
p=1,2, \ldots ., N_{i} \\
j=1,2, \ldots \ldots ., k
\end{array}\right\} \text { for } i=1,2, \ldots . ., k
$$

where $\mathrm{X}$ is a set of individual characteristics determining an individual's destination at time t, $\beta_{\mathrm{ij}}$ is a conformable vector of parameters for the ijth transition, and $\mathrm{N}_{\mathrm{i}}$ and $\mathrm{k}$ are defined as above ${ }^{2}$.

The required elements of the transition matrix, $\Omega$, can then be found from these estimated probabilities by taking an average across different groups of individuals. For example, suppose a steady state labour market distribution is required for a sub-group of the working age population (e.g., classified according to gender, qualifications, age, etc.), then the elements of $\Omega^{\mathrm{m}}$ for this group of individuals, say the $m$ th group, are found from:

$$
\hat{\omega}_{i j}^{m}=\frac{1}{N_{i}^{m}} \sum_{p=1}^{N_{i}^{m}} \frac{\exp ^{X_{p} \hat{\beta}_{i j}}}{\sum_{j=1}^{k} \exp _{p} \hat{\beta}_{i j}} \quad \text { for } i=1,2, \ldots, k \text { and } j=1,2, \ldots ., k
$$

That is the estimated transition probabilities are averages of the estimated probabilities from the multinomial logit model, where the average in each case is based on the number of individuals in the $m$ th group occupying labour market state $i$ at time $\mathrm{t}-1$,

\footnotetext{
${ }^{2}$ In the multinomial logit model the sum of probabilities across each of the $\mathrm{k}$ possible outcomes must by definition equal unity. As a result of this only k-1 parameters sets are needed to determine the k outcome probabilities. When estimating a multinomial model, therefore, one set of parameters can be normalized to zero. In each of the specifications reported below the labour market state chosen for this normalization was always the largest group.
} 
$\mathrm{N}_{\mathrm{i}}^{\mathrm{m}}$. Expression (9), therefore, is a parametric version of expression (7). However, using expression (9) to simulate the transition probabilities for different groups of individuals does have certain advantages, particularly when the numbers of individuals falling within a group of interest are not large enough to justify the use of observed transition probabilities. For this reason expression (9) was typically used to estimate the elements of $\Omega$ used in the analysis reported below. However, in order to allow a comparison to be made between the steady states produced by these two separate methods, in some cases steady state labour market distributions derived from both methods are shown alongside one another. Somewhat reassuringly, the distributions produced by each method were virtually identical.

Finally estimates of the transition matrix are also used to provide an estimate of the duration different types of individuals are likely to stay in jobs paid at or below the NMW. Specifically if the exit probability from being paid at or below the NMW for individuals belonging to the $m$ th group is $\lambda_{m}$, then these individuals can expect to remain at or below the NMW for:

$$
\mathrm{E}\left(\mathrm{D}_{\mathrm{NMW}}^{\mathrm{m}}\right)=\frac{1}{\lambda_{\mathrm{m}}}
$$

where $E\left(D_{N M W}^{m}\right)$ is the expected time paid at or below the NMW for individuals in the $m$ th group and $\lambda_{\mathrm{m}}$ is found by summing the (k-1) elements in the ith row of $\Omega^{\mathrm{m}}$ showing the exit probabilities of individuals employed at or below the NMW at time t-1 to other labour market destinations at time t, i.e., $\lambda_{\mathrm{m}}=\sum_{\mathrm{j} \neq \mathrm{i}} \omega_{\mathrm{ij}}^{\mathrm{m}}$. 


\section{DATA}

The analysis is based on the longitudinal element of the Labour Force Survey (LFS) ${ }^{3}$. The LFS is a quarterly household survey, which collects information on a range of labour market issues. Individuals enter the survey in wave 1 and then remain in the survey for 5 subsequent waves (one year) on a strict rotational basis. Hence in each quarter of the LFS one-fifth of individuals will be having their first interview and onefifth their last interview. This rotational element to the LFS creates an 80 per cent overlap between quarters and thus 20 per cent of the sample enter and exit the survey each quarter. As questions relating to labour market income are only asked in waves 1 and 5 of the LFS, annual longitudinal data sets provided by the Office of National Statistics were used in the analysis reported below. These longitudinal data sets are derived from the information provided by individuals at their first and fifth interviews ${ }^{4}$. Thus while the time period covered by any given longitudinal data set is one calendar year, longitudinal data sets can be created on a quarterly basis. For this analysis, therefore, we used 15 longitudinal sets running from Spring 1999/2000 to Autumn 2002/2003 ${ }^{5}$. Each data set contained approximately 10,000 individuals from which we pre-selected only those individuals that were adults and of working age (i.e. those aged 22 or more but less than 65 and 60 for men and women respectively) ${ }^{6}$.

\footnotetext{
3 The British Household Panel Survey (BHPS) was considered as a possible alternative to the LFS. However, although the BHPS tracks individuals over a longer time period and records information on individuals full work history it is not possible to calculate a wage rate for any job changes that occur between annual interviews. For this reason, and because the LFS is a much larger survey, we decided to base the analysis on the LFS.

${ }^{4}$ As a result the analysis focuses only on labour market transitions observed between waves 1 and 5 .

${ }^{5}$ To coincide with the implementation of the NMW the Spring quarter of 1999 was defined as starting in April.

${ }^{6}$ Choosing to base the analysis on adults only removed the added complication of having to deal with the development rate for individuals aged between 18 and 21. However, the results of the analysis were not sensitive to this restriction.
} 
Before any analysis could be undertaken an important data issue that needed to be decided on was what pay measure should be used in the analysis? Two pay measures are currently provided in the LFS. One is a derived hourly pay measure, which is known to be subject to measurement error as it includes bonuses and other pay, which are not normally included in the basic hourly wage rate. The other is a direct hourly wage rate variable, which was introduced into the LFS in March 1999 as an attempt to address some of the problems associated with the derived pay measure. The use of the direct measure of hourly pay has been shown to offer certain advantages over the derived hourly pay measure, particularly when issues of compliance with NMW legislation are being considered (see Dickens and Manning, 2004). However, the downside to using this measure is that it is only available for a limited number of respondents, namely those paid by the hour; and even though Stewart and Swaffield (2002) have shown that almost 83 per cent of the beneficiaries of the minimum wage are hourly paid the limited coverage provided by the measure - only about 40 per cent of those in employment - mean that it is not really suitable for estimating the steady state labour market distributions needed in this paper. For this reason, therefore, we decided to base our analysis on the derived hourly pay rate ${ }^{7}$.

Choosing to use the derived hourly pay measure does, however, have an important implication for the way in which the analysis is subsequently conducted. The problem stems from the well known fact that unlike the direct measure of hourly pay the derived hourly pay measure in the LFS does not have a clearly identified mass point of data at the NMW. To illustrate this point we compared the percentage of workers paid exactly the minimum wage to the percentage that were paid below the national minimum using

\footnotetext{
${ }^{7}$ The alternative of using the method suggested by Skinner et al (2002) to simulate missing data on the direct hourly pay measure was not considered appropriate in this case because the impact of the procedure would be to swap one kind of measurement error for another.
} 
both the derived and direct measures of pay. Using the direct pay measure 1.2 per cent were paid below the minimum while 5.8 per cent were paid the national minimum exactly. Using the derived hourly pay measure the equivalent figures were 5.5 per cent and 0.3 per cent respectively. As there is too small a number of individuals paid exactly the national minimum under the derived pay measure to model transitions we took the pragmatic step of defining those individuals paid at or below the NMW to be group most likely to be affected by the legislation.

\section{RESULTS}

Some preliminary insights into extent to which individuals move across different labour market boundaries are provided by the transition rates reported in Table 2. These transition rates are calculated on the basis of expression (7) and are based on the results obtained from analysing transitions that occurred between the Spring quarter of 1999/00 and the Autumn quarter of 2002/03. Four labour market destinations are distinguished in the analysis, $(\mathrm{k}=4)$, namely paid at or below the NMW, paid above the NMW, unemployed (ILO definition), and economically inactive. Separate transition matrices are reported for (i) all individuals of working age (i.e., for males and females combined), (ii) for males only, and (iii) for females only. Three features of the data are worth noting.

First, according to Table 2 section (i), which shows the transition matrix for all individuals, it can be seen that 32.3 per cent of individuals that are paid at or below the NMW at their initial interview remain in that state at their final interview one year later, 55.6 per cent move to employment above the NMW in the same period, 2.9 per cent exit to unemployment, and 9.2 per cent become inactive. Second, movements into 
employment paid at or below the NMW from other labour market destinations are small in relative terms, only 5.1 per cent from unemployment, 3.1 per cent from employment above the NMW and 1.4 per cent from economic inactivity, even though the numbers involved relative to the stock of individuals paid at or below the NMW can be quite large depending on the size of the stock from which the inflow originates. Third, men are more likely to move out of minimum wage employment than women (60.8 per cent of men move from minimum wage employment to higher wage employment compared to only 54.1 per cent of women, i.e., Table 2 sections (ii) and (iii) respectively). Thus, while these transitions rates suggest a measure of persistence at wages at or below the NMW for some workers, for the majority minimum wage employment seems to be only a temporary phenomenon.

Of course it is possible that many workers who exit pay at or below the NMW do so to jobs that only pay just above the NMW. To check this possibility we divided those moving out of pay at or below the minimum into higher paying jobs into ranges of $5 \%$, $10 \%, 20 \%, 30 \%$ and $50 \%$ above the NMW. The results of this exercise are shown in Table 3, and two things stand out from it. First, for many moving to pay positions above the NMW the adjustment is substantial, particularly as the period covered by the data is just 12 months. Second, not only are men more likely to move out of minimum wage payment into higher pay than women, but the size of the upward adjustment is also typically greater for men than it is for women. Along with the information provided in Table 2, therefore, these data suggests significant upward mobility in this lower segment of the earnings distribution. 


\section{The Transition Model (Multinomial Logit Estimates)}

The variables used to estimate the transition model described by expression (8) are fairly standard and include a range of personal characteristics (e.g. age, gender, qualifications), household characteristics (e.g. number of dependent children), type of housing tenure, and regional and time dummies ${ }^{8}$. In addition for those individuals that were employed at their first interview a set of variables relating to their current job (e.g. industry sector, employment tenure) were also included. The value taken for each variable was determined by the responses given by an individual at their first interview, and a full description of the variables used in the analysis is provided in Table A1 in the appendix along with variable means tabulated by labour market status in Table A2.

The results of estimating the multinomial transition model for each of the four labour market states identified in the analysis are shown in Tables 4 to 7 . The estimates underpinning these results are used to construct the transition matrices needed to calculate the steady state distributions described by expression (6). Each set of estimates, therefore, takes the labour market status reported by an individual at their first interview and then considers the probability of an individual either remaining in that state at their last interview or of exiting to another labour market destination during the same period. Thus, for illustrative purposes, Table 4 considers the position of individuals initially paid at or below the NMW at their initial interview and then considers whether they remained at or below the NMW at their final interview, or moved to employment above the NMW, unemployment, or economic inactivity. Similarly, Table 5 considers what happens to individuals that were initially paid above

\footnotetext{
${ }^{8}$ Time dummies are included in the model for two reasons. First, they allow for the effect that common macroeconomic shocks may have on labour market transition rates. Second, and equally important, they capture any effect on transition rates caused by changes in the NMW, particularly where such changes may have had implications for the severity of the policy.
} 
the NMW, and Tables 6 and 7 does the same for individuals that were either initially unemployed or economically inactive respectively.

The main column headings reported in Tables 4 to 7 indicate potential labour market destinations, while the column entries themselves show marginal probability effects. These indicate the effect that a designated variable has on the probability of an individual occupying each of the different labour market destinations identified at the end of the year given the position they occupied at the start of the year ${ }^{9}$. Thus in Table 4 the entries for males show that relative to women, men initially employed at or below the NMW are 3.7 per cent less likely to be in employment at or below the NMW by the end of the year, 6.1 per cent more likely to move to employment above the NMW, 1.3 per cent more likely to move to unemployment, and 3.6 per cent less likely to move to economic inactivity ${ }^{10}$. The stars reported at the side of each marginal effect indicate the significance of the effect, with one star indicating significance at the 10 per cent level, two stars significance at the 5 per cent level, and three stars significance at the 1 per cent level.

As the primary purpose of the analysis reported in Tables 4 to 7 is to estimate steady state labour market distributions for different groups of individuals, it is not necessary to give a blow-by-blow of these results. However, a number of features of the results reported in Tables 4 to 7 are worth highlighting, and they can be described on a tableby-table as follows.

\footnotetext{
${ }^{9}$ Marginal effects are calculated on the basis of average characteristics and account is taken of the nature of $1 / 0$ variables by evaluating the change in the probability of an individual moving to different labour market destinations when the variable takes the value 1 or 0 .

${ }^{10}$ The sum of the marginal probabilities reported in each row of these tables should by definition equal zero. Where they do not this is due to the effects of rounding.
} 
Those Initially Employed At or Below the NMW (Table 4)

Individuals with qualifications are significantly less likely to remain at or below the NMW and more likely to exit to employment above the NMW than individuals without formal academic qualifications. Moreover, this qualifications effect is clearly graduated, with those with higher (degree-level) qualifications being less likely to stay at or below the NMW than those with lower level qualifications.

Homeowners with a mortgage are less likely to remain at or below the NMW and are more likely to exit to employment above the NMW than individuals occupying other tenure types. On the other hand individuals in private rented or other accommodation are less likely to move to employment above the NMW and seem either more likely to stay in employment at or below the NMW or exit to economic inactivity.

There are relatively few significant industry effects identified. However, individuals employed in both Transport and Communications and Banking and Finance are less likely to remain at or below the NMW and more likely to exit to employment above the NMW than individuals employed in other industries.

Temporary contracts workers are more likely to exit employment at or below the NMW than individuals on permanent contracts. However, their destination is less likely to be to jobs paying wages above the NMW and is much more likely to be to a spell of economic inactivity. Thus individuals on temporary contacts are almost 10 per cent more likely to exit to economic inactivity than otherwise comparable individuals on permanent contracts. 
The characteristics most closely associated with an individual remaining at or below the NMW are being employed in a small firm, working part-time, or being employed in the private sector. For example, an individual employed in a small firm is 10 per cent more likely to remain in employment in a job paid at or below the NMW than an individual in a large firm, while comparable figures for a part time and private sector worker are 5 per cent and 7 per cent respectively.

\section{Those Initially Employed at or Above the NMW (Table 5)}

The marginal effects reported in Tables 5 show that men and individuals with qualifications are most likely to remain in employment at or above the NMW; while factors that increase the probability of an individual leaving employment above the NMW to other labour market destinations are having a work limiting disability, having young children, working part time or on a temporary contract, and being employed in either a small firm or in the private sector.

The counterpart to these findings is that the probability of moving from employment above the NMW to employment below the NMW is higher for each of the following groups: women, individuals with no formal academic qualifications, people with disabilities, part-time workers, and those employed initially on temporary contacts. However, it should be noted that the marginal effects reported in Tables 5 for some of these groups is often quite small.

Similarly the probability of exiting from employment above the NMW to economic inactivity is higher for women, for individuals with a work limiting disability, for individuals with young children, for individuals working either part-time or in the 
private sector, and for those employed on temporary contracts who are also more likely to exit to unemployment.

\section{Those Initially Unemployed (Table 6)}

The likelihood of remaining unemployed is significantly higher for men, for individuals living in public rented accommodation, and both singles and non-whites. By way of contrast those most likely to exit unemployment to other labour market destinations include individuals with qualifications; those who are either married, widowed, separated or divorced; and mortgage holders.

According to the marginal effects reported in Table 6 men are less much likely than women to exit unemployment to either minimum wage employment or economic inactivity, while individuals with qualifications are much more likely to exit unemployment to jobs paid at or above the NMW than individuals with no qualifications. Similarly individuals with qualifications also seem less likely to exit unemployment to economic inactivity or minimum wage employment, although the marginal effects reported for an exit from unemployment to minimum wage employment were only found to be significant for individuals with higher-level qualifications.

As might be expected Table 6 indicates that individuals with a work limiting disability are significantly less likely to exit unemployment for employment above the NMW but are more likely to exit to economic inactivity as are individuals with young children. Finally, while it was noted earlier that married individuals were significantly more likely to leave unemployment for other labour market destinations, the size of the 
marginal effects reported in Table 6 suggests that the probability of an exit to employment at above the NMW is substantially larger than an exit to either employment at or below the NMW or economic inactivity.

\section{Those Initially Inactive (Table 7)}

Men are less likely to remain economically inactive and more likely to move to unemployment from economic inactivity than women. Men are also less likely to move to minimum wage employment from economic inactivity than women but while the estimated marginal effect reported for this transition in Table 7 is statistically significant the overall magnitude is quite small, and amounts to less than half a per cent.

Individuals with higher qualifications are least likely to remain economically inactive and more likely to move to employment above the NMW than otherwise comparable individuals. The educational effects reported in Table 7 are strongest for those with degrees and weakest for those with other qualifications, such that compared to an individual with no qualifications the probability of remaining economically inactive is 6 per cent lower for people with degrees and under-4 per cent lower for those other qualifications.

Finally other characteristics associated with remaining economically inactive include having a work limiting disability, the presence of young children, and being non-white. For example a person with a disability is 7 per cent more likely to remain economically inactive than an otherwise comparable individual, while the corresponding marginal 
effects reported for the presence of young children and being non-white were 2.6 per cent and 1.2 per cent respectively.

\section{Steady State Distributions and Estimated Durations At or Below the NMW}

Steady state labour market distributions, based on the results reported in Tables 4 to 7 and expression (6), are shown in Table $8^{11}$. The first three rows of Table 8 show the steady state distributions for males and females combined and then individual distributions for men and women separately; the figures in parentheses show steady state labour market distributions derived from a non-parametric estimator of the transition matrix (i.e., found from using expression (7) to estimate each $\omega_{\mathrm{ij}}$ ). The steady state distributions based on the non-parametric method of estimating the transition matrix are included in Table 8 in order to allow a comparison to be made between the distributions produced by this estimator and the parametric method (i.e., those based on using expression (9) to estimate each $\omega_{\mathrm{ij}}$ ). As is clear from entries in the first three rows of Table 8 both methods produce virtually identical results, which implies that the parametric method of estimating the transition matrix is as good as the non-parametric method of tracking movements across each of the four labour market states identified in the analysis.

The steady state distributions shown in Table 8 show that the proportion of the population at risk who are paid at or below the NMW is higher for women (5.6 per cent of all women aged 22-59 compared to 1.8 per cent of men aged 22-64), the young (4.3

\footnotetext{
${ }^{11}$ The steady state distributions reported for workforce characteristics are found by taking individuals in employment at time $\mathrm{t}-1$ that have a particular characteristic and then simulating the transition rates found from estimates of expression (8). For characteristics common to all four labour market states, transition rates are still found from estimates of (8) but in this case the predictions from each multinomial logit model are based on the sample of individuals found in each state at time $\mathrm{t}-1$.
} 
per cent of all 22-34 year olds but only 1.9 per cent of those aged 55-64), and for those with no qualifications (5.8 per cent of all individuals aged 22 to 64 with no qualifications compared to 1.5 per cent of individuals aged 22 to 64 with higher qualifications). In terms of employment related characteristics Table 8 also indicates that the incidence of being paid at or below the NMW is higher for part-time workers (8.8 per cent for part time workers compared to 2.5 per cent for full time workers); for individuals employed in small establishments (6.9 per cent for individuals employed in small firms compared to 3.1 per cent for individuals employed in larger firms); for private sector workers (5.2 per cent for private sector workers compared to 2.8 per cent in the public sector), for those with shorter job tenure (6.1 per cent for tenure of less than a year, 5.2 pre cent for those with tenure between 1 and five years, and 3.3 per cent for those with job tenure exceeding five years); for workers employed in Distribution, Hotels and Restaurants (8.9 per cent)and for those employed on temporary contracts (4.8 per cent of workers on temporary contracts).

Similarly the incidence of those paid above the NMW is higher for individuals with qualifications (81 per cent of individuals with higher qualifications are paid above the NMW compared to only 35 per cent of those with no qualifications); for those living in the South-East and East-Anglia (just over 71 per cent of workers in these two regions can be expected to be re paid above the NMW); for those without a work limiting disability (75 per cent for those without a disability compared to 24 per cent of individuals with a disability); for those working in larger firms or the public sector (82 per cent and 84 per cent respectively); and for those on permanent contacts and who have been with their current employer longer. 
Although the primary focus of the analysis is on the position of workers paid at or below the NMW it is worth noting that the steady state distributions for both unemployment and inactivity mostly conform to expectations. The steady state values for unemployment and inactivity are 3 per cent and 28 per cent respectively for the full sample, and both unemployment and inactivity incidences tend to vary in line with the usual suspects. Thus unemployment incidences are higher for men, for individuals with no qualifications, singles, and the young; while inactivity rates tend to be higher among the least qualified, the old, among individuals with work limiting disabilities, and for individuals living in the North, and Wales ${ }^{12}$.

Finally, exit probabilities calculated on the basis of the information provided by the transition matrices are used to estimate expected durations at or below the NMW for different types of individuals using expression (10). The results of this exercise are reported in Tables 9 and 10; Table 9 for personal characteristics and Table 10 for employment-related characteristics. For the full sample the probability of exiting employment at or below the NMW is estimated to be 0.67 , which implies an average expected duration of about 1.48 years on pay at or below the NMW. Exit probabilities from the NMW are estimated to be higher for young workers aged 22-34 (0.74) and lower for individuals with low qualifications (0.60). So the time a young worker can expect to be employed at or below the NMW is shorter than that expected by a worker with low qualifications. Similarly Table 9 indicates that the time an individual can expect to remain in a job paid at or below the NMW is higher for women than for men, for workers in the North compared to workers in other regions, and for those with a work limiting disability.

\footnotetext{
${ }^{12}$ However, the inactivity rate estimated for those aged 55-64 does seem to be implausibly large and should therefore be treated with caution.
} 
Turning to employment related characteristics reported in Table 10, expected durations at or below the NMW are longer for part-time employees (1.55 years for part time workers compared to 1.38 years fro full time workers); for those employed in Agriculture and Fishing (1.65 years); for workers in small firms (1.59 years for workers in small firms compared to 1.36 years for workers in larger firms); and for those employed in the private sector (1.51 years for private sector workers compared to 1.39 years for public sector workers). However, while Tables 9 and 10 both indicate that exit probabilities and expected durations at or below the NMW can vary for different types of workers, the differences reported are not that dramatic - e.g. on the basis of expected duration measure the difference between the highest and lowest values is only 0.35 of a year (i.e., the difference between 1.66 years for workers with no qualifications and 1.31 years for workers employed in Transport and Communications). As suggested in Table 2, therefore, for a majority of workers the duration of employment on or below the minimum wage is not long-term, and as a result they do not appear to be permanently trapped in NMW employment.

\section{CONCLUSION}

The evidence reported in this paper suggests that the incidence and duration of time at or below the NMW vary for different types of individuals. However, the evidence on low pay dynamics revealed by the analysis of the LFS is consistent with that found in the United States in so far as minimum wage jobs are of relatively short-duration Most important from the policy point of view is that a substantial number of those paid at or below the minimum wage move after a short period into higher paid employment and for over half of them the upward adjustment in pay is in excess of $10 \%$ above the minimum. As our estimates also suggest that only about 3.8 per cent of the eligible 
adult workforce in the UK are likely to be affected by the legislation these results seem to offer a plausible explanation of why most work done on the NMW in the UK to date has found it to have had only a benign effect on employment outcomes. In this context, therefore, future work might consider how future up ratings made to the NMW that have the effect of increasing its bite and severity are likely to change these positive conclusions. 
Table 1: UK National Minimum Wage Rates (£ per hour)

\begin{tabular}{|c|c|c|}
\hline & Adult Rate & Youth Rate \\
\hline April 1999 & 3.60 & 3.00 \\
\hline June 2000 & 3.60 & 3.20 \\
\hline October 2000 & 3.70 & 3.20 \\
\hline October 2001 & 4.10 & 3.50 \\
\hline October 2002 & 4.20 & 3.60 \\
\hline October 2003 & 4.50 & 3.80 \\
\hline October 2004 & 4.85 & 4.10 \\
\hline October 2005 & 5.05 & 4.25 \\
\hline
\end{tabular}

Table 2: Transition Rates: LFS Estimates Spring 1999 to Autumn 2003, Derived Hourly Earnings - Adults Only

\begin{tabular}{|c|c|c|c|c|}
\hline \multicolumn{5}{|c|}{ Males and Females Combined } \\
\hline Origin & $\begin{array}{c}\text { At or Below } \\
\text { NMW }\end{array}$ & Above NMW & Unemployed & Inactive \\
\hline $\begin{array}{c}\text { At or Below } \\
\text { NMW }\end{array}$ & 0.323 & 0.556 & 0.029 & 0.092 \\
\hline Above NMW & 0.031 & 0.963 & 0.013 & 0.030 \\
\hline Unemployed & 0.051 & 0.318 & 0.374 & 0.257 \\
\hline Inactive & 0.014 & 0.059 & 0.036 & 0.891 \\
\hline \multicolumn{5}{|c|}{ Males Only } \\
\hline \multicolumn{5}{|c|}{ Destination } \\
\hline Origin & $\begin{array}{c}\text { At or Below } \\
\text { NMW }\end{array}$ & Above NMW & Unemployed & Inactive \\
\hline $\begin{array}{c}\text { At or Below } \\
\text { NMW }\end{array}$ & 0.263 & 0.608 & 0.054 & 0.075 \\
\hline Above NMW & 0.015 & 0.948 & 0.015 & 0.022 \\
\hline Unemployed & 0.033 & 0.305 & 0.455 & 0.208 \\
\hline Inactive & 0.005 & 0.037 & 0.040 & 0.918 \\
\hline \multicolumn{5}{|c|}{ Females Only } \\
\hline \multicolumn{7}{|c|}{ Destination } \\
\hline Origin & At or Below & Above NMW & Unemployed & Inactive \\
\hline $\begin{array}{c}\text { At or Below } \\
\text { NMW }\end{array}$ & 0.340 & 0.541 & 0.022 & 0.097 \\
\hline Above NMW & 0.047 & 0.905 & 0.010 & 0.037 \\
\hline Unemployed & 0.073 & 0.335 & 0.273 & 0.319 \\
\hline Inactive & 0.018 & 0.071 & 0.034 & 0.877 \\
\hline
\end{tabular}


Table 3: LFS Estimates Spring 1999 to Autumn 2003 According to Degree of Upward Mobility. Origin at or Below the NMW and Destination Above the NMW

\begin{tabular}{|c|c|c|}
\hline & Below $+\mathbf{5 \%}$ & Above + $\mathbf{5 \%}$ \\
\hline All & 13.11 & 86.9 \\
\hline Men & 10.4 & 89.6 \\
\hline Women & 14.1 & 85.9 \\
\hline All & Below $+\mathbf{1 0} \%$ & Above $+\mathbf{1 0} \%$ \\
\hline Men & 24.4 & 75.6 \\
\hline Women & 17.1 & 82.9 \\
\hline & 27.2 & 72.8 \\
\hline All & Below $+\mathbf{2 0} \%$ & Above $+\mathbf{2 0} \%$ \\
\hline Men & 41.4 & 58.6 \\
\hline Women & 32.8 & 67.2 \\
\hline & 44.6 & 55.4 \\
\hline All & Below $+\mathbf{3 0} \%$ & Above $+\mathbf{3 0} \%$ \\
\hline Men & 56.4 & 43.6 \\
\hline Women & 45.9 & 54.1 \\
\hline & 60.3 & 39.7 \\
\hline All & Below $+\mathbf{5 0} \%$ & Above $+\mathbf{5 0} \%$ \\
\hline Men & 71.9 & 28.1 \\
\hline Women & 62.8 & 37.2 \\
\hline & 75.3 & 24.7 \\
\hline
\end{tabular}


Table 4: Origin At or Below the NMW - Marginal Effects

\begin{tabular}{|c|c|c|c|c|}
\hline \multirow[b]{2}{*}{ Origin At or Below the NMW } & \multicolumn{4}{|c|}{ Destination } \\
\hline & $\begin{array}{c}\text { At or Below } \\
\text { NMW }\end{array}$ & $\begin{array}{l}\text { Above the } \\
\text { NMW }\end{array}$ & Unemployed & Inactive \\
\hline & $\begin{array}{l}\text { Marginal } \\
\text { Effect }\end{array}$ & $\begin{array}{l}\text { Marginal } \\
\text { Effect }\end{array}$ & $\begin{array}{c}\text { Marginal } \\
\text { Effect }\end{array}$ & $\begin{array}{c}\text { Marginal } \\
\text { Effect }\end{array}$ \\
\hline Male & -0.037 & $0.061 * *$ & $0.013 *$ & $-0.036 * * *$ \\
\hline Higher Education & $-0.083 * * *$ & $0.124^{* * *}$ & $-0.014 * * *$ & $-0.027 * *$ \\
\hline A-level & $-0.073 * * *$ & $0.069 * *$ & -0.003 & 0.007 \\
\hline O-Level & $-0.062 * * *$ & $0.078 * * *$ & -0.002 & -0.014 \\
\hline Other Qualifications & $-0.061^{* * *}$ & $0.070 * * *$ & 0.003 & -0.012 \\
\hline Married & -0.024 & 0.018 & 0.009* & -0.003 \\
\hline Widowed/Separated/Divorced & -0.017 & 0.002 & $0.025 *$ & -0.009 \\
\hline Mortgage & $-0.062 * *$ & $0.054 * *$ & 0.001 & 0.007 \\
\hline Public Rented & -0.002 & -0.017 & 0.004 & 0.016 \\
\hline Private Rented and Other & 0.043 & $-0.076 *$ & -0.007 & 0.039 \\
\hline Disability & 0.025 & $-0.164 * * *$ & 0.011 & $0.129 * * *$ \\
\hline Dependent Children & 0.005 & -0.015 & 0.001 & $0.009 *$ \\
\hline Child Under 4 & -0.035 & -0.032 & -0.001 & $0.069 * * *$ \\
\hline Part Time & $0.049 * *$ & $-0.061 * * *$ & -0.004 & 0.016 \\
\hline Small Firm & $0.102^{* * *}$ & $-0.121 * * *$ & $0.009 * *$ & 0.010 \\
\hline Private Sector & $0.074 * * *$ & $-0.081 * * *$ & 0.000 & 0.007 \\
\hline Agriculture and Fishing & -0.017 & 0.050 & -0.004 & -0.029 \\
\hline Manufacturing/Energy/Water & -0.038 & -0.008 & 0.028 & 0.018 \\
\hline Construction & -0.056 & 0.060 & 0.014 & -0.018 \\
\hline Distribution/Hotels/Restaurants & -0.036 & 0.025 & 0.005 & 0.006 \\
\hline Transport and Communications & $-0.097 * *$ & $0.119 * *$ & -0.002 & -0.019 \\
\hline Banking, Finance and Insurance & $-0.082 * *$ & $0.080 * *$ & 0.000 & 0.001 \\
\hline \begin{tabular}{|c|} 
Public Administration, Education \\
and Health \\
\end{tabular} & 0.000 & 0.008 & -0.003 & -0.005 \\
\hline Non White & 0.075 & -0.080 & 0.014 & -0.009 \\
\hline Temporary Contract & $-0.050 *$ & -0.054 & 0.010 & $0.094 * * *$ \\
\hline Tenure & 0.000 & 0.000 & $0.000 * *$ & 0.000 \\
\hline $2000 / 01$ & -0.014 & 0.035 & -0.006 & -0.016 \\
\hline $2001 / 02$ & $0.046 * *$ & $-0.039 *$ & 0.004 & -0.011 \\
\hline $2002 / 03$ & 0.017 & -0.006 & 0.001 & -0.012 \\
\hline Log likelihood & -3203.498 & & & \\
\hline $\mathrm{N}$ & 3425 & & & \\
\hline LR $\chi^{2}$ & $\begin{array}{l}486.74 \\
(0.000)\end{array}$ & & & \\
\hline
\end{tabular}

Notes: $*, * *, * * *$ indicate significance of marginal effect at the $10 \%, 5 \%$ and $1 \%$ level respectively. The specification from which these marginal effects were derived also included a constant, regional dummies and a quadratic in age. p-value for the $\chi^{2}$ test in parenthesis. 
Table 5: Origin Above the NMW - Marginal Effects

\begin{tabular}{|c|c|c|c|c|}
\hline \multirow[b]{2}{*}{ Origin Above the NMW } & \multicolumn{4}{|c|}{ Destination } \\
\hline & $\begin{array}{c}\text { At or Below } \\
\text { NMW }\end{array}$ & $\begin{array}{c}\text { Above the } \\
\text { NMW }\end{array}$ & Unemployed & Inactive \\
\hline & $\begin{array}{l}\text { Marginal } \\
\text { Effect }\end{array}$ & $\begin{array}{l}\text { Marginal } \\
\text { Effect }\end{array}$ & $\begin{array}{c}\text { Marginal } \\
\text { Effect }\end{array}$ & $\begin{array}{c}\text { Marginal } \\
\text { Effect }\end{array}$ \\
\hline Male & $-0.009 * * *$ & $0.023 * * *$ & 0.001 & $-0.014 * * *$ \\
\hline Higher Education & $-0.021 * * *$ & $0.020 * * *$ & 0.001 & -0.001 \\
\hline A-level & $-0.011 * * *$ & $0.013 * * *$ & -0.001 & -0.001 \\
\hline O-Level & $-0.009 * * *$ & $0.011^{* * *}$ & 0.000 & -0.001 \\
\hline Other Qualifications & $-0.006 * * *$ & $0.007 * * *$ & 0.000 & -0.001 \\
\hline Married & $0.002 *$ & -0.003 & $-0.002 * *$ & $0.003^{*}$ \\
\hline Widowed/Separated/Divorced & -0.001 & 0.000 & -0.001 & 0.001 \\
\hline Mortgage & $-0.005 * * *$ & $0.018 * * *$ & $-0.004 * * *$ & $-0.009 * * *$ \\
\hline Public Rented & $0.007 * * *$ & $-0.017 * * *$ & $0.003^{*}$ & $0.007 * * *$ \\
\hline Private Rented and Other & -0.001 & 0.004 & 0.000 & $-0.004 *$ \\
\hline Disability & $0.004 * *$ & $-0.044 * * *$ & $0.005^{* * *}$ & $0.035 * * *$ \\
\hline Dependent Children & $0.001^{* * *}$ & $-0.002 * *$ & 0.000 & 0.001 \\
\hline Child Under 4 & $-0.005 * * *$ & $-0.014 * * *$ & 0.002 & $0.017 * * *$ \\
\hline Part Time & $0.021 * * *$ & $-0.037 * * *$ & -0.001 & $0.017 * * *$ \\
\hline Small Firm & $0.008 * * *$ & $-0.011 * * *$ & 0.001 & $0.002 * * *$ \\
\hline Private Sector & $0.012^{* * *}$ & $-0.027 * * *$ & $0.006 * * *$ & $0.008 * * *$ \\
\hline Agriculture and Fishing & $-0.006 * *$ & 0.007 & 0.002 & -0.004 \\
\hline Manufacturing/Energy/Water & $-0.006 * * *$ & -0.006 & 0.003 & $0.009 * *$ \\
\hline Construction & $-0.009 * * *$ & 0.006 & 0.003 & 0.000 \\
\hline Distribution/Hotels/Restaurants & 0.002 & -0.006 & 0.001 & 0.003 \\
\hline Transport and Communications & $-0.006 * * *$ & 0.004 & -0.002 & 0.003 \\
\hline Banking, Finance and Insurance & $-0.009 * * *$ & 0.004 & 0.002 & 0.003 \\
\hline \begin{tabular}{|c|} 
Public Administration, Education \\
and Health \\
\end{tabular} & 0.000 & 0.002 & -0.003 & 0.002 \\
\hline Non White & 0.003 & $-0.017 * * *$ & $0.009 * * *$ & 0.004 \\
\hline Temporary Contract & $0.006^{* * *}$ & $-0.048 * * *$ & $0.023 * * *$ & $0.020 * * *$ \\
\hline Tenure & $0.000 * * *$ & $0.000 * * *$ & $-0.000 * * *$ & $0.000 * * *$ \\
\hline $2000 / 01$ & 0.000 & -0.001 & -0.001 & 0.002 \\
\hline $2001 / 02$ & $0.003 * * *$ & $-0.007 * * *$ & 0.002 & 0.002 \\
\hline $2002 / 03$ & 0.002 & $-0.005 * *$ & $0.002 *$ & 0.001 \\
\hline Log likelihood & \begin{tabular}{|l|}
-17271.998 \\
\end{tabular} & & & \\
\hline $\mathrm{N}$ & 57596 & & & \\
\hline $\operatorname{LR} \chi^{2}(126)$ & $\begin{array}{c}4578.820 \\
(0.000)\end{array}$ & & & \\
\hline
\end{tabular}

Notes: $*, * *, * * *$ indicate significance of marginal effect at the $10 \%, 5 \%$ and $1 \%$ level respectively. The specification from which these marginal effects were derived also included a constant, regional dummies and a quadratic in age. p-value for the $\chi^{2}$ test in parenthesis. 
Table 6: Origin Unemployed - Marginal Effects

\begin{tabular}{|c|c|c|c|c|}
\hline \multirow[b]{2}{*}{ Origin Unemployed } & \multicolumn{4}{|c|}{ Destination } \\
\hline & \begin{tabular}{|c|} 
At or Below \\
NMW
\end{tabular} & \begin{tabular}{|c|} 
Above the \\
NMW
\end{tabular} & Unemployed & Inactive \\
\hline & $\begin{array}{c}\text { Marginal } \\
\text { Effect }\end{array}$ & \begin{tabular}{|c|} 
Marginal \\
Effect
\end{tabular} & $\begin{array}{c}\text { Marginal } \\
\text { Effect }\end{array}$ & $\begin{array}{c}\text { Marginal } \\
\text { Effect }\end{array}$ \\
\hline Male & $-0.030 * * *$ & 0.009 & $0.164 * * *$ & $-0.143 * * *$ \\
\hline Higher Education & $-0.021 * *$ & $0.245 * * *$ & $-0.135 * * *$ & $-0.089 * * *$ \\
\hline A-level & -0.012 & $0.137 * * *$ & $-0.065 * *$ & $-0.061^{* * *}$ \\
\hline O-Level & -0.001 & $0.115^{* * * *}$ & $-0.077 * * *$ & -0.037 \\
\hline Other Qualifications & 0.016 & $0.099 * * *$ & $-0.070 * * *$ & $-0.046^{*}$ \\
\hline Married & $0.020 * *$ & $0.123 * * *$ & $-0.206 * * *$ & $0.063 * * *$ \\
\hline Widowed/Separated/Divorced & 0.021 & $0.065 * *$ & $-0.087 * * *$ & 0.001 \\
\hline Mortgage & -0.013 & $0.061 * *$ & $-0.049 *$ & 0.001 \\
\hline Public Rented & $-0.019 *$ & $-0.111 * * *$ & $0.078^{* * *}$ & $0.051^{* *}$ \\
\hline Private Rented and Other & -0.006 & $-0.075 * *$ & 0.057 & 0.025 \\
\hline Disability & 0.003 & $-0.082 * * *$ & -0.029 & $0.109 * * *$ \\
\hline Dependent Children & 0.000 & -0.016 & 0.005 & 0.012 \\
\hline Child Under 4 & -0.013 & -0.008 & -0.044 & $0.064 * *$ \\
\hline Non White & $-0.019 *$ & $-0.094 * * *$ & $0.129 * * *$ & -0.016 \\
\hline $2000 / 01$ & 0.000 & 0.024 & -0.029 & 0.005 \\
\hline $2001 / 02$ & 0.003 & $0.041 *$ & $-0.059 * *$ & 0.015 \\
\hline $2002 / 03$ & $0.025^{*}$ & 0.025 & $-0.062 * *$ & 0.012 \\
\hline Log likelihood & -3594.721 & & & \\
\hline $\mathrm{N}$ & 3197 & & & \\
\hline $\operatorname{LR} \chi^{2}(90)$ & $\begin{array}{c}693.440 \\
(0.000) \\
\end{array}$ & & & \\
\hline
\end{tabular}

Notes: *,**,*** indicate significance of marginal effect at the $10 \%, 5 \%$ and $1 \%$ level respectively. The specification from which these marginal effects were derived also included a constant, regional dummies and a quadratic in age. p-value for the $\chi^{2}$ test in parenthesis. 
Table 7: Origin Inactive - Marginal Effects

\begin{tabular}{|c|c|c|c|c|}
\hline \multirow[b]{2}{*}{ Origin Inactive } & \multicolumn{4}{|c|}{ Destination } \\
\hline & \begin{tabular}{|c} 
At or Below \\
NMW
\end{tabular} & \begin{tabular}{|c|} 
Above the \\
NMW
\end{tabular} & Unemployed & Inactive \\
\hline & $\begin{array}{c}\text { Marginal } \\
\text { Effect }\end{array}$ & $\begin{array}{c}\text { Marginal } \\
\text { Effect }\end{array}$ & $\begin{array}{c}\text { Marginal } \\
\text { Effect }\end{array}$ & $\begin{array}{c}\text { Marginal } \\
\text { Effect }\end{array}$ \\
\hline Male & $-0.004 * * *$ & $0.011^{* * * *}$ & $0.023^{* * *}$ & $-0.030^{* * *}$ \\
\hline Higher Education & -0.001 & $0.044 * * *$ & $0.017 * * *$ & $-0.061^{* * *}$ \\
\hline A-level & 0.000 & $0.030^{* * *}$ & $0.010^{* * *}$ & $-0.040^{* * *}$ \\
\hline O-Level & 0.002 & $0.024 * * *$ & $0.011^{* * *}$ & $-0.037^{* * *}$ \\
\hline Other Qualifications & $0.005^{* *}$ & $0.020^{* * *}$ & $0.011^{* * *}$ & $-0.035^{* * *}$ \\
\hline Married & 0.000 & $0.009 * * *$ & $-0.014 * * *$ & 0.005 \\
\hline Widowed/Separated/Divorced & 0.000 & $0.017 * * *$ & 0.003 & $-0.021^{* * *}$ \\
\hline Mortgage & 0.003 & $0.009 * * *$ & $0.010^{* * *}$ & $-0.021^{* * *}$ \\
\hline Public Rented & -0.001 & $-0.012 * * *$ & $0.020^{* * *}$ & -0.007 \\
\hline Private Rented and Other & 0.000 & $-0.007 * *$ & $0.023 * * *$ & $-0.016 * *$ \\
\hline Disability & $-0.008^{* * *}$ & $-0.040 * * *$ & $-0.023 * * *$ & $0.070^{* * *}$ \\
\hline Dependent Children & 0.000 & $-0.002 * *$ & $-0.002 *$ & $0.004^{* * * *}$ \\
\hline Child Under 4 & $-0.002 * *$ & $-0.013^{* * *}$ & $-0.011 * * *$ & $0.026 * * *$ \\
\hline Non White & $-0.006 * * *$ & $-0.013 * * *$ & $0.007 *$ & $0.012^{* *}$ \\
\hline $2000 / 01$ & -0.001 & 0.000 & -0.001 & 0.002 \\
\hline $2001 / 02$ & $0.004 * * *$ & $-0.005^{* *}$ & -0.001 & 0.002 \\
\hline $2002 / 03$ & 0.001 & -0.004 & 0.000 & 0.003 \\
\hline Log likelihood & -9325.169 & & & \\
\hline $\mathrm{N}$ & 23500 & & & \\
\hline $\operatorname{LR} \chi^{2}(90)$ & $\begin{array}{c}2440.800 \\
(0.000)\end{array}$ & & & \\
\hline
\end{tabular}

Notes: $*, * *, * * *$ indicate significance of marginal effect at the $10 \%, 5 \%$ and $1 \%$ level respectively. The specification from which these marginal effects were derived also included a constant, regional dummies and a quadratic in age. $\mathrm{p}$-value for the $\chi^{2}$ test in parenthesis. 
Table 8: Steady State Labour Market Distributions LFS Estimates- Adults Only

\begin{tabular}{|c|c|c|c|c|}
\hline Group & $\begin{array}{l}\text { At or Below the } \\
\text { NMW }\end{array}$ & $\begin{array}{l}\text { Above the } \\
\text { NMW }\end{array}$ & Unemployment & Inactivity \\
\hline All & $0.038(0.038)$ & $0.649(0.648)$ & $0.031(0.031)$ & $0.281(0.282)$ \\
\hline Male & $0.018(0.018)$ & $0.650(0.651)$ & $0.040(0.041)$ & $0.292(0.291)$ \\
\hline Female & $0.056(0.056)$ & $0.624(0.622)$ & $0.025(0.025)$ & $0.296(0.297)$ \\
\hline Highest qualification & 0.015 & 0.809 & 0.023 & 0.153 \\
\hline Intermediate qualification & 0.038 & 0.700 & 0.029 & 0.232 \\
\hline Low qualification & 0.058 & 0.350 & 0.042 & 0.550 \\
\hline Single & 0.035 & 0.697 & 0.050 & 0.218 \\
\hline Married & 0.038 & 0.642 & 0.022 & 0.299 \\
\hline Widowed/Separated/Divorced & 0.044 & 0.606 & 0.043 & 0.307 \\
\hline Northern & 0.052 & 0.597 & 0.031 & 0.319 \\
\hline Yorkshire/Humberside & 0.045 & 0.612 & 0.035 & 0.308 \\
\hline East Midlands & 0.049 & 0.677 & 0.031 & 0.243 \\
\hline East Anglia & 0.041 & 0.714 & 0.024 & 0.222 \\
\hline London & 0.017 & 0.655 & 0.043 & 0.284 \\
\hline South East & 0.034 & 0.714 & 0.025 & 0.227 \\
\hline South West & 0.044 & 0.685 & 0.022 & 0.249 \\
\hline West Midlands & 0.044 & 0.641 & 0.033 & 0.282 \\
\hline North West & 0.037 & 0.632 & 0.033 & 0.298 \\
\hline Wales & 0.042 & 0.617 & 0.022 & 0.319 \\
\hline Scotland & 0.035 & 0.632 & 0.033 & 0.300 \\
\hline Age 22-34 & 0.043 & 0.741 & 0.036 & 0.181 \\
\hline Age 35-44 & 0.042 & 0.783 & 0.027 & 0.149 \\
\hline Age 45-54 & 0.035 & 0.594 & 0.028 & 0.342 \\
\hline Age 55-retirement & 0.019 & 0.229 & 0.026 & 0.726 \\
\hline Disability & 0.024 & 0.243 & 0.037 & 0.695 \\
\hline No Disability & 0.041 & 0.751 & 0.029 & 0.179 \\
\hline \multicolumn{5}{|c|}{ Employment Related Characteristics } \\
\hline Full Time & 0.025 & 0.846 & 0.027 & 0.102 \\
\hline Part Time & 0.088 & 0.616 & 0.026 & 0.270 \\
\hline Agriculture and Fishing & 0.053 & 0.759 & 0.041 & 0.146 \\
\hline Manufacturing/Energy/Water & 0.029 & 0.786 & 0.038 & 0.147 \\
\hline Construction & 0.023 & 0.835 & 0.036 & 0.106 \\
\hline Distribution/Hotels/Restaurants & 0.089 & 0.685 & 0.034 & 0.192 \\
\hline Transport and Communications & 0.027 & 0.828 & 0.026 & 0.119 \\
\hline Banking, Finance and Insurance & 0.028 & 0.818 & 0.030 & 0.123 \\
\hline $\begin{array}{l}\text { Public Administration, Education } \\
\text { and Health }\end{array}$ & 0.037 & 0.818 & 0.017 & 0.129 \\
\hline Small Firm & 0.069 & 0.719 & 0.032 & 0.180 \\
\hline Large firm & 0.031 & 0.819 & 0.025 & 0.125 \\
\hline Private Sector & 0.052 & 0.759 & 0.034 & 0.155 \\
\hline Public Sector & 0.028 & 0.839 & 0.016 & 0.117 \\
\hline
\end{tabular}




\begin{tabular}{|c|c|c|c|c|}
\hline Temporary Contract & 0.048 & 0.640 & 0.059 & 0.252 \\
\hline Permanent Contract & 0.043 & 0.796 & 0.026 & 0.135 \\
\hline Tenure less than 1 year & 0.061 & 0.745 & 0.040 & 0.153 \\
\hline Tenure between 1 and 5 years & 0.052 & 0.788 & 0.031 & 0.129 \\
\hline Tenure more than 5 years & 0.033 & 0.799 & 0.022 & 0.146 \\
\hline
\end{tabular}

\section{Notes:}

1. Steady states given in parenthesis are based on the transition matrices reported in Table 2.

2. Highest qualification includes degree or other higher education, intermediate qualification include ' $\mathrm{O}$ ' levels, ' $\mathrm{A}$ ' levels and equivalent and no qualifications means no qualifications at all. 
Table 9: Probability of Exit from the NMW and Average Expected Duration At or Below the NMW by Individual Characteristics

\begin{tabular}{|c|c|c|}
\hline Group & Exit probability & Duration \\
\hline All & 0.67 & 1.48 \\
\hline Male & 0.73 & 1.37 \\
\hline Female & 0.66 & 1.52 \\
\hline Highest qualification & 0.73 & 1.36 \\
\hline Intermediate qualification & 0.70 & 1.42 \\
\hline Low qualification & 0.60 & 1.66 \\
\hline Single & 0.71 & 1.41 \\
\hline Married & 0.67 & 1.48 \\
\hline Widowed/Separated/Divorced & 0.63 & 1.59 \\
\hline Northern & 0.60 & 1.65 \\
\hline Yorkshire/Humberside & 0.69 & 1.46 \\
\hline East Midlands & 0.65 & 1.53 \\
\hline East Anglia & 0.69 & 1.45 \\
\hline London & 0.79 & 1.27 \\
\hline South East & 0.67 & 1.50 \\
\hline South West & 0.66 & 1.51 \\
\hline West Midlands & 0.65 & 1.54 \\
\hline North West & 0.68 & 1.46 \\
\hline Wales & 0.71 & 1.41 \\
\hline Scotland & 0.70 & 1.43 \\
\hline Age 22-34 & 0.74 & 1.36 \\
\hline Age 35-44 & 0.66 & 1.51 \\
\hline Age 45-54 & 0.63 & 1.58 \\
\hline Age 55-retirement & 0.65 & 1.55 \\
\hline Disability & 0.65 & 1.53 \\
\hline No Disability & 0.68 & 1.47 \\
\hline
\end{tabular}

Note: Qualifications defined as in Table 8 
Table 10: Probability of Exit and Average Expected Duration At or Below the NMW by Employment Related Characteristics - Adults Only

\begin{tabular}{|c|c|c|}
\hline Group & Exit probability & Duration \\
\hline Full Time & 0.72 & 1.38 \\
\hline Part Time & 0.65 & 1.55 \\
\hline Agriculture and Fishing & 0.61 & 1.65 \\
\hline Manufacturing/Energy/Water & 0.71 & 1.41 \\
\hline Construction & 0.73 & 1.37 \\
\hline Distribution/Hotels/Restaurants & 0.65 & 1.53 \\
\hline Transport and Communications & 0.76 & 1.31 \\
\hline Banking, Finance and Insurance & 0.73 & 1.38 \\
\hline Other Services & 0.68 & 1.48 \\
\hline Small Firm & 0.63 & 1.59 \\
\hline Large firm & 0.73 & 1.36 \\
\hline Private Sector & 0.66 & 1.51 \\
\hline Public Sector & 0.72 & 1.39 \\
\hline Temporary Contract & 0.75 & 1.33 \\
\hline Permanent Contract & 0.67 & 1.50 \\
\hline Tenure less than 1 year & 0.68 & 1.47 \\
\hline Tenure between 1 and 5 years & 0.68 & 1.47 \\
\hline Tenure more than 5 years & 0.66 & 1.50 \\
\hline
\end{tabular}




\section{Data Appendix}

Table A1: LFS Variable definitions

\begin{tabular}{|c|c|}
\hline Variable name & Definition \\
\hline Male & 1 if the individual is male; 0 otherwise \\
\hline Higher Education & $\begin{array}{l}1 \text { if the individual has a degree or other higher } \\
\text { education qualification; } 0 \text { otherwise }\end{array}$ \\
\hline A-level & $\begin{array}{l}1 \text { if the individual has a ' } A \text { ' level or equivalent } \\
\text { education qualification; } 0 \text { otherwise }\end{array}$ \\
\hline O-Level & $\begin{array}{l}1 \text { if the individual has a ' } O \text { ' level or equivalent } \\
\text { education qualification; } 0 \text { otherwise }\end{array}$ \\
\hline Other Qualifications & $\begin{array}{l}1 \text { if the individual has an other qualification; } 0 \\
\text { otherwise }\end{array}$ \\
\hline No Qualifications & $\begin{array}{l}1 \text { if the individual has no qualifications; } 0 \text { otherwise } \\
\text { (omitted category) }\end{array}$ \\
\hline Age & Individual's age in years \\
\hline Northern & $\begin{array}{l}1 \text { if the individuals lives in the Northern region; } 0 \\
\text { otherwise }\end{array}$ \\
\hline Yorkshire/Humberside & $\begin{array}{l}1 \text { if the individuals lives in Yorkshire and } \\
\text { Humberside; } 0 \text { otherwise }\end{array}$ \\
\hline East Midlands & 1 if the individuals lives in East Midlands; 0 otherwise \\
\hline East Anglia & 1 if the individuals lives in East Anglia; 0 otherwise \\
\hline London & 1 if the individuals lives in London; 0 otherwise \\
\hline South East & $\begin{array}{l}1 \text { if the individuals lives in the South East; } 0 \text { otherwise } \\
\text { (omitted category) }\end{array}$ \\
\hline South West & 1 if the individuals lives in South West; 0 otherwise \\
\hline West Midlands & $\begin{array}{l}1 \text { if the individuals lives in the West Midlands; } 0 \\
\text { otherwise }\end{array}$ \\
\hline North West & 1 if the individuals lives in North West; 0 otherwise \\
\hline Wales & 1 if the individuals lives in Wales; 0 otherwise \\
\hline Scotland & 1 if the individuals lives in Scotland; 0 otherwise \\
\hline Northern Ireland & $\begin{array}{l}1 \text { if the individual lives in Northern Ireland; } 0 \\
\text { otherwise }\end{array}$ \\
\hline Single & $\begin{array}{l}1 \text { if the individual is single and has never been } \\
\text { married; } 0 \text { otherwise (omitted category) }\end{array}$ \\
\hline Married & 1 if the individual is married; 0 otherwise \\
\hline Widowed/Separated/Divorced & $\begin{array}{l}1 \text { if the individual is separated, divorced or widowed; } \\
0 \text { otherwise }\end{array}$ \\
\hline Own Outright & $\begin{array}{l}1 \text { if the individuals home is owned outright; } 0 \\
\text { otherwise (omitted category) }\end{array}$ \\
\hline Mortgage & $\begin{array}{l}1 \text { if the individuals home is owned with a mortgage; } 0 \\
\text { otherwise }\end{array}$ \\
\hline Public Rented & $\begin{array}{l}1 \text { if the individuals home is rented or rent free from } \\
\text { local authority, Scottish homes, new town } \\
\text { development or housing association, co-op, trust; } 0 \\
\text { otherwise }\end{array}$ \\
\hline Private Rented and Other & $\begin{array}{l}1 \text { if the individuals home is part rent, squatting or } \\
\text { rented or rent free from employing organization, }\end{array}$ \\
\hline
\end{tabular}




\begin{tabular}{|c|c|}
\hline & $\begin{array}{l}\text { another organization, relative, individual employer or } \\
\text { other private landlord; } 0 \text { otherwise }\end{array}$ \\
\hline Dependent Children & $\begin{array}{l}\text { number of dependent children under } 19 \text { in family and } \\
\text { person is head/spouse }\end{array}$ \\
\hline Child Under 4 & $\begin{array}{l}1 \text { if the individual has a dependent child in family } \\
\text { aged under } 4 \text { and person is head/spouse; } 0 \text { otherwise }\end{array}$ \\
\hline Disability & $\begin{array}{l}1 \text { if the individual has a work limiting disability; } 0 \\
\text { otherwise }\end{array}$ \\
\hline Non-White & 1 if the individual is non-white; 0 otherwise \\
\hline $1999 / 00$ & $\begin{array}{l}1 \text { if individual surveyed between 1999-2000; } 0 \\
\text { otherwise (omitted category) }\end{array}$ \\
\hline $2000 / 01$ & $\begin{array}{l}1 \text { if individual surveyed between 2000-2001; } 0 \\
\text { otherwise }\end{array}$ \\
\hline 2001/02 & $\begin{array}{l}1 \text { if individual surveyed between 2001-2002; } 0 \\
\text { otherwise }\end{array}$ \\
\hline $2002 / 03$ & $\begin{array}{l}1 \text { if individual surveyed between 2002-2003; } 0 \\
\text { otherwise }\end{array}$ \\
\hline \multicolumn{2}{|r|}{ Employed } \\
\hline Part-Time & 1 if the individual is employed part time; 0 otherwise \\
\hline Agriculture and Fishing & $\begin{array}{l}1 \text { if the individual is employed in agriculture and } \\
\text { fishing; } 0 \text { otherwise }\end{array}$ \\
\hline Manufacturing/Energy/Water & $\begin{array}{l}1 \text { if the individual is employed in energy and water or } \\
\text { manufacturing; } 0 \text { otherwise }\end{array}$ \\
\hline Construction & $\begin{array}{l}1 \text { if the individual is employed in construction; } 0 \\
\text { otherwise }\end{array}$ \\
\hline Distribution/Hotels/Restaurants & $\begin{array}{l}1 \text { if the individual is employed in distribution, hotels } \\
\text { and restaurants; } 0 \text { otherwise }\end{array}$ \\
\hline Transport and Communications & $\begin{array}{l}1 \text { if the individual is employed in transport and } \\
\text { communication; } 0 \text { otherwise }\end{array}$ \\
\hline $\begin{array}{l}\text { Banking, Finance and } \\
\text { Insurance }\end{array}$ & $\begin{array}{l}1 \text { if the individual is employed in banking, finance and } \\
\text { insurance; } 0 \text { otherwise }\end{array}$ \\
\hline $\begin{array}{l}\text { Public Administration, } \\
\text { Education and Health }\end{array}$ & $\begin{array}{l}1 \text { if the individual is employed in public } \\
\text { administration, education or health; } 0 \text { otherwise }\end{array}$ \\
\hline Other Services & $\begin{array}{l}1 \text { if the individual is employed in other services; } 0 \\
\text { otherwise (omitted category) }\end{array}$ \\
\hline Small Firm & $\begin{array}{l}1 \text { if the individual is employed in an organisation with } \\
\text { less than } 25 \text { employees; } 0 \text { otherwise }\end{array}$ \\
\hline Private Sector & $\begin{array}{l}1 \text { if the individual is employed in the private sector; } 0 \\
\text { otherwise }\end{array}$ \\
\hline Temporary Contract & $\begin{array}{l}1 \text { if the individual is employed in a non permanent } \\
\text { position; } 0 \text { otherwise }\end{array}$ \\
\hline Tenure & length of time continuously employed in months \\
\hline
\end{tabular}


Table A2: LFS Summary Statistics: Means by Labour Market Status

\begin{tabular}{|c|c|c|c|c|}
\hline & At or below NMW & Above NMW & Unemployed & Inactive \\
\hline Male & 0.24 & 0.50 & 0.56 & 0.35 \\
\hline Higher Education & 0.10 & 0.31 & 0.16 & 0.13 \\
\hline A-level & 0.18 & 0.23 & 0.19 & 0.18 \\
\hline O-Level & 0.27 & 0.23 & 0.23 & 0.19 \\
\hline Other Qualifications & 0.19 & 0.12 & 0.17 & 0.15 \\
\hline Age & 39.08 & 40.68 & 38.14 & 44.01 \\
\hline Northern & 0.08 & 0.05 & 0.08 & 0.07 \\
\hline Yorkshire/Humberside & 0.11 & 0.09 & 0.09 & 0.09 \\
\hline East Midlands & 0.09 & 0.07 & 0.06 & 0.07 \\
\hline East Anglia & 0.03 & 0.03 & 0.03 & 0.03 \\
\hline London & 0.04 & 0.08 & 0.12 & 0.11 \\
\hline South West & 0.11 & 0.10 & 0.07 & 0.07 \\
\hline West Midlands & 0.10 & 0.09 & 0.09 & 0.08 \\
\hline North West & 0.09 & 0.09 & 0.10 & 0.11 \\
\hline Wales & 0.05 & 0.05 & 0.05 & 0.06 \\
\hline Scotland & 0.10 & 0.10 & 0.12 & 0.10 \\
\hline Northern Ireland & 0.03 & 0.02 & 0.04 & 0.05 \\
\hline Married & 0.59 & 0.66 & 0.40 & 0.60 \\
\hline Widowed/Separated/Divorced & 0.14 & 0.12 & 0.16 & 0.17 \\
\hline Mortgage & 0.54 & 0.73 & 0.36 & 0.35 \\
\hline Public Rented & 0.23 & 0.08 & 0.38 & 0.32 \\
\hline Private Rented & 0.07 & 0.05 & 0.10 & 0.07 \\
\hline Dependent Children & 0.14 & 0.08 & 0.22 & 0.46 \\
\hline Child Under 4 & 0.92 & 0.81 & 0.75 & 0.87 \\
\hline Disability & 0.14 & 0.16 & 0.15 & 0.20 \\
\hline Non-White & 0.04 & 0.03 & 0.10 & 0.08 \\
\hline $2000 / 01$ & 0.25 & 0.27 & 0.26 & 0.27 \\
\hline $2001 / 02$ & 0.25 & 0.27 & 0.26 & 0.28 \\
\hline $2002 / 03$ & 0.19 & 0.19 & 0.18 & 0.19 \\
\hline Part-Time & 0.63 & 0.23 & & \\
\hline Small Firm & 0.57 & 0.29 & & \\
\hline Private Sector & 0.79 & 0.63 & & \\
\hline Agriculture and Fishing & 0.02 & 0.01 & & \\
\hline Manufacturing/Energy/Water & 0.10 & 0.20 & & \\
\hline Construction & 0.02 & 0.05 & & \\
\hline Distribution/Hotels/Restaurants & 0.39 & 0.15 & & \\
\hline Transport and Communications & 0.04 & 0.07 & & \\
\hline Banking, Finance and Insurance & 0.08 & 0.15 & & \\
\hline Public Administration, Education and Health & 0.26 & 0.33 & & \\
\hline Temporary Contract & 0.09 & 0.05 & & \\
\hline Tenure & 53.95 & 104.26 & & \\
\hline
\end{tabular}

Means relate to regression sample and refer to labour market status at wave 1. 


\section{References}

Arulampalam, W., Booth, A. and Bryan, M. (2004). 'Training and the new minimum wage', Economic Journal, 114, C87-C94.

Asplund, R., Sloane, P.J. and Theodossiou, I, editors. (1998). Low Pay and Earnings Mobility in Europe, Aldershot, Edward Elgar.

Dickens, R. (2001). 'The national minimum wage', In Dickens, R., Wadsworth, J. and Gregg, P. (eds), The State of Working Britain, York Publishing Services, York.

Department of Trade and Industry (DTI), (2004). Government Evidence to the Low Pay Commission, www.dti.gov.uk/er/nmw/index.htm.

Dex, S., Sutherland, H. and Joshi, H. (2000). 'Effects of minimum wages on the gender pay gap’, National Institute Economic Review, 173, pp 80-88

Dickens, R. and Manning, A. (2004). 'Has the national minimum wage reduced UK wage inequality?', Journal of the Royal Statistical Society, Series A, 167, pp 613-626

Evan, W.E. and Macpherson, D.A. (2003). 'The wage and employment dynamics of minimum wage workers’, Southern Economic Journal, 69, pp 676-690

Machin, S., Manning, A. and Rahman, L. (2003). 'Where the national minimum wage bites hard: the introduction of the national minimum wage to a low wage sector', Journal of the European Economic Association, 1, pp 154-180.

Metcalf, D. (2002). 'The national minimum wage: coverage, impact and future', Oxford Bulletin of Economics and Statistics, 64, Supplement, pp 567-582.

Metcalf, D. (2004). 'The impact of the national minimum wage on the pay distribution, employment and training’, Economic Journal, 114, C84-C86.

Neumark, D. and Nizalova, O. (2004). 'Minimum wage effects in the longer run', IZA Discussion Paper, No. 11428.

Ransom, M. and Oaxaca, R. (2005). 'Intrafirm mobility and sex differences in pay', Industrial and Labor Relations Review, 58, pp219-237.

Robinson, H. (2002).'Wrong side of the track: the impact of the minimum wage on gender pay gaps in Britain', Oxford Bulletin of Economics and Statistics, 64, pp 417448.

Skinner, S., Stuttard, N., Beissel-Durrant, G., and Jenkins, J. (2002). 'The measurement of low pay in the UK Labour Force Survey', Oxford Bulletin of Economics and Statistics, 64, supplement, pp. 653-676

Sloane, P.J. and Theodossiou, I. (2000). 'Earnings mobility of the low paid', in Gregory, M., Salverda, W. and Bazen, S., editors, Labour Market Inequalities, Oxford, Oxford University Press. 
Smith, R.E. and Vavrichek, B. (1992). 'The wage mobility of minimum wage workers', Industrial and Labor Relations Review, 46, pp. 82-88.

Stewart, M. (2002). 'Estimating the impact of the minimum wage using geographical wage variation', Oxford Bulletin of Economics and Statistics, 64, supplement, pp. 583605.

Stewart, M. and Swaffield, J.K. (2002). 'Using the BHPS wave 9 additional questions to evaluate the impact of the national minimum wage', Oxford Bulletin of Economics and Statistics, 64, supplement, pp. 633-52

Stewart, M. and Swaffield, J. (1999). 'Low pay dynamics and transition probabilities', Economica, 66, pp 23-42. 